\title{
How do political elites persist? Political selection, political inequality and empirical historical research
}

\author{
Brenda Van Coppenolle*
}

How do political elites persist? Populist movements highlight the continued tension between citizens and political elites. This article reviews some recent research on political selection and inequality. I consider political inequality as the persistent political selection of specific individuals or their relatives over time. Empirical historical research employing statistical analysis of natural experiments can help to understand the connection between specific democratic institutions, such as elections or lotteries, and political selection, political behaviour, or political inequality over time. Some democratic features enable elites to persist, yet there is much variation in political inequality over time and space. Further research could aim to disentangle institutional causes of this variation from determinants of institutional choice.

*Email: b.vancoppenolle@essex.ac.uk, Lecturer, Department of Government, University of Essex, Colchester. 


\section{Introduction}

How do political elites persist? In this article, I review selected research on who legislators are, how democratic institutions affect their selection and behaviour, as well as their persistence over the long run. The extent to which political elites persist,

forms a measure of the level of political inequality between elites and citizens. I argue that political inequality in societies can be measured as the extent to which the same individuals, or families, monopolize political power. This operationalization travels well through space and time. In extreme forms of non-competitiveness, power is passed on within political dynasties, and power becomes essentially hereditary.

Democratic competition is meant to break up the extreme political inequality associated with absolute, hereditary politics. We still insufficiently understand the exact institutional reforms under which hereditary political selection declined during European countries' evolution towards representative democracy (e.g. Offerlé, 1993) from the individual interests of those who decided to reform (Benoit, 2004, Capoccia and Ziblatt 2010). Yet these questions were crucial for early elite theorists (e.g. Michels ([1911] 1968), Mosca ([1896] 1939)) who warned that all power has a tendency to become hereditary. To understand how institutions affect political selection, and long-run political inequality, we need to understand why individuals support (and largely continue to support) ${ }^{1}$ the institutional equilibriums that make up their representative democracies. For this non-exhaustive review I draw on examples from the study of political inequality and political selection, broadly defined, and present some of my own recent contributions to this literature, about historical lotteries, legislative elites, and political dynasties in France and Britain. The focus in this work on highly unequal, early democratising countries addresses two important research 
challenges. First, we need to observe the evolution of political inequality over the very long run. Second, political elites rarely experiment with drastic institutional change for political appointments. They are unlikely to agree to experiment with lotteries today. Empirical historical research might address some of these challenges.

This article sets out how we can think of political inequality as elite persistence: The continuing political selection of particular types of elites. Recent studies refocus on political elites as the central actors, e.g. on political dynasties. Such recent empirical work on political elites often employs an historical, individual and quantitative lens. Some of these studies revisit political history, and employ research designs suitable to causal inference. ${ }^{2}$ Political inequality in democracies can persist through individual incumbency advantages in elections and promotions, which are sometimes even transferable to family relatives.

\section{Political inequality through the lens of political selection}

Research on political elites is making a come-back after being out of fashion for many decades. Most older studies considered political elites in temporal or spatial isolation. This includes some seminal contributions on political elites from historians and historical sociologists (e.g. Canandine, 1999, Offerlé, 1993, Rush, 2001, Wasson, 1991). With the maturation of mass democracy, the focus moved from political elites to understanding the constraints on their actions, e.g. parties, movements, and institutions, and the quality of representation. In representative democracies, citizens do not participate directly in forming policy, but instead periodically select political 
elites in elections to represent their interests (Manin, 1997). So, scholars concerned with levels of political inequality in representative democracies have traditionally conceptualized such inequality as representation, the extent to which politicians form a mirror image of the groups of citizens they represent.

\subsection{Political inequality and representation}

Democracy as we know it today is representative democracy; individuals periodically elect others to represent their interests rather than participate directly in forming policy. Representative democracy and elections as mechanism for political selection emerged in the 19th century as autocratic elites agreed to open access to politics (Ihl and Déloye, 1991, Sintomer, 2011). Individual direct participation in political decision-making was impractical, and some would argue also unnecessary as long as different interests were sufficiently represented. Yet do legislatures reflect the societies they represent?

While the principle of 'one (wo)man one vote' in democracies sounds fair, political scientists have spent decades studying how that equal stake is given very different weights, depending on the institutional set-ups of countries or the behaviour of for example interest groups. For example, there is a long tradition of studying representation in parliament. Typically, political scientists have studied political (in)equality as representation, and considered individual behaviour and background characteristics like socio-economic or immigrant status (e.g. Norris, 2004, Pitkin 1967). Others have focused on the behaviour of legislators in their legislative roles (Blomgren and Rozenberg, 2012, Brouard et al., 2013). Yet which behaviour is consistent with group as opposed to individual interests? Which groups warrant 
consideration if political equality is defined as representation? Despite offering crucial insights on representative democracy, the approach has a number of limitations.

Cross-national research on representation is difficult, because how can we know which characteristics are politically relevant? ${ }^{3}$ Characteristics that indicate 'elite' or 'unrepresentative' status in one country do not necessarily do so in another country or at a different point in time. Yet even within the same country and at a given moment in time, it is unclear how much different individual characteristics matter: Is it equally bad for representation if highly educated individuals are overrepresented in parliament, than if certain regions of a country are under-represented? Finally, it is complicated to infer from legislators' behaviour that their decisions can be explained by their individual background and interests, their party label, or their electoral and career concerns (Krehbiel, 1993). Moreover, after having agreed on the relevant interests to be represented in parliament, could there not be a trade-off between representation and political quality or accountability?

While studying political inequality as representation is difficult, it is easier to say what is not very convincingly democratic: concentration of power over time. In the extreme scenario, a small number of individuals hold most of political power, and are able to pass this power on to their relatives and friends with similar individual characteristics.

\subsection{Political inequality as concentration in political selection}

I propose to consider political inequality as the temporal persistence of the same

political elites. I argue that political inequality can be measured as the extent to which the same individuals, or families, monopolize political power in parliaments 
and executives. Persistence of individuals and families by definition runs counter to representation. The benefit of this definition of political inequality is that it can travel more easily through time and space. Comparing parliamentary political dynasties across time and countries has only recently been made possible by advances in data collection and methods of analysis. The study of political dynasties provides underappreciated, comparative insights about representation, such as the link between high levels of dynasties in parliaments, and the electoral system (see for example Smith, 2018). In fact, the puzzle of whether and why elites moved away from hereditary politics in democracies has long been recognized (e.g. Offerlé, 1993), but remains insufficiently understood from the perspective of individual interests. The Iron Law of Oligarchy posits that even in democracies power tends to be concentrated in very few hands and we should expect that "every class has a tendency to become hereditary, in practice if not in law" (Michels ([1911] 1968), Mosca, ([1896] 1939)). An important research challenge for this literature is to disentangle institutional effects from the determinants of initial choices.

Considering elites as a measure of political inequality is necessarily limiting, but reflects a comparable shift to the study of top incomes to gain new insights into economic inequality (Piketty, 2014). A focus on legislative and executive elites, and how they are selected, is justified as these individuals ultimately set policy, and it is the selection of these individuals that voters typically control in democracies. As economic inequality increases, there is a broadly shared concern about the evolution of political selection and whether present-day changes in the economic interests of representatives are affecting democratic decision-making (McCarty, Poole and Rosenthal, 2005). Yet we need to define how economic and political inequality are distinct, before we can consider to what extent they are related (Acemoglu et al., 
2008). The study of the concentration of political power among the same or related legislative elites offers a promising way forward.

Whether incumbency and political dynasties are always bad for democracy is an open question. Yet it is clear that in its extreme form, democracy necessarily disappears and only a narrow section of interests are represented: hereditary politics reigns. How can we specify which type of political selection is adversarial for representation in democracy? Principal-agent theory forms a framework that helps to understand when and why representation by a narrow elite is problematic.

\subsection{Political inequality and adverse political selection}

In a principal-agent framework where voters select representatives to act in their interest, it becomes clear that there are two main concerns that derive from information asymmetries between representatives and the represented: moral hazard (a representative's behaviour), but also adverse selection (a politician's group or type). If voters care only about their representative's behaviour, they should only care about a politician's type insofar as that affects their behaviour. In other words, who a politician is should not matter beyond "substantive representation" (Pitkin 1967). Indeed, in a standard citizen-candidate model, citizen-candidates can only credibly commit to implementing the policies preferred by citizens of the same group after they are elected (Osborne and Slivinski, 1996, Besley and Coate, 1997). Yet if even individuals from a given group can differ, because they are more or less capable of interpreting their voters' interests and they have better information about their type than voters, then the problem of potential adverse selection becomes even more extensive. This is particularly the case if some individuals, say those who hold more education, can 
more credibly signal that they will be 'good' representatives.

So, beyond group identification, voters may also care about their representative's type if it includes an aspect of 'political quality', for example how efficient they are at 'getting things done'. These individual aspects are often called valence characteristics (Ansolabehere, Snyder and Stewart, 2000, Schofield, 2003): characteristics that everyone prefers more of in their representative, such as honesty, altruism, intelligence, charisma. If politicians vary in such 'political quality', principal-agent theory can help explain why adverse selection in political selection can exist as a result of the institutional set-up (Besley, 2005). The wrong types of individuals may be attracted to a career in politics, and deter other more talented or more honest newcomers from entering. Equilibria of bad politicians, i.e. of low political quality, once established can persist (Caselli and Morelli, 2000, Mattozzi and Merlo, 2007, 2008, Messner and Polborn, 2004). In extreme scenarios, this could also lead to captured democracies, whereby a small oligarchy takes only their own economic self-interest into account in setting policy (Acemoglu, 2008). Some institutions may force voters to trade-off quality and representation. For example, poor and middle-class voters may support elite candidates, even though these can only credibly commit to their preferred policy of low taxation and limited redistribution, if such elite representatives are at the same time better able to secure pork for the voter's district (Mattozzi and Snowberg, 2018).

Political quality in these theoretical contributions was generally assumed to be a fixed characteristic, determined before a politician's first entry. Yet political quality is likely to increase over time with experience, or may only be revealed over time. This means political selection must not only be considered at the time of election. We must also study political selection over a legislator's career, for promotions within their party or within the legislature. 
If political selection of specific political types or qualities takes place repeatedly over time, whether adverse or positive, it can result in high levels of political inequality. That is, the political elites may be consistently drawn from similar backgrounds that are different from the population as a whole. Political inequality can for example manifest itself in the persistence of existing (pre-democracy) elites.

\subsection{Does political selection matter?}

Does it matter for political outcomes who politicians are? We know from a number of studies that the identity of representatives, or their specific individual characteristics like their caste, family composition in terms of gender, or eduction, influences the policy choices they make (e.g. Pande, 2003, Washington, 2009, Besley and ReynalQuerol, 2011). We also know that the set-up of democratic institutions, and specifically the electoral system, matters for the types of individual characteristics that voters select their representatives on. For example, when given a choice over individual politicians from the same party label, voters tend to prefer representatives local to their districts, particularly as these districts increase in size (Shugart, Valdini, and Suominen, 2005). ${ }^{4}$ Yet political quality is difficult to measure, and studies have approached measurement differently.

\section{Determinants of political inequality}

If political inequality can be measured by concentration among elites, we should compare the effects of different selection institutions on such concentration over space and time. It is notoriously difficult to distinguish the effects of democratic institutions from the underlying, pre-existing inequalities of the societies that implement them. 
The limited variation in real-world institutions makes this challenge particularly severe for comparative analysis. Democratic institutions are rarely drastically changed, making it hard to establish that specific institutional change in itself reduces or reproduces political inequality. Recent empirical contributions, using contemporary and historical data, therefore increasingly employ quantitative analysis of natural or quasi-natural experiments ${ }^{5}$ to address this research challenge.

\subsection{Measuring political quality and political inequality}

How should the political quality of political elites be measured, and compared? Empirical research measuring political quality, like the literature on representation, has to first decide which characteristics matter. Individual characteristics such as localness, family background, or caste do not fully capture what we tend to think that the political quality concept covers. Some have attempted to measure political quality more directly, as years of schooling, previous political experience and previous market income. Parties anticipating quality-seeking voters select higher quality politicians, allow them to run in the most competitive districts, and place them in the most competitive spots within the party list (Galasso and Nannicini, 2011; 2015). Some argue that democracies create higher growth than non-democracies precisely because of the more limited variance in the quality of the leaders they select (Besley, Montalvo and Reynal-Querol, 2011), though others found that leaders' education was unrelated to corruption, legislative productivity or electoral success (Carnes and Lupu, 2015).

Consider education as a measure of political quality. We know that entry to elite education in many countries is still biased to those with parents who have 
enjoyed such an education themselves (e.g. Falcon and Bataille, 2018). Education can offer existing elites a (for voters perfectly legitimate) comparative advantage over newcomers. For example, this mechanism was found to explain the persistent overselection of ministers from certain regions with historically higher colonial education rates in sixteen former British and French colonies (Ricart-Huguet, 2019). For the United Kingdom, we analysed a large dataset of legislators between 1832 and 2010. We found that a persistent and sizeable proportion of the parliament and cabinet were educated not only at elite universities, but even at a much younger age at one of the famous public schools, which still only allow entry to boys. Yet proportions in the political elite remained remarkably stable over time, in spite of franchise and candidate eligibilty extensions (Berlinski, Dewan and Van Coppenolle, 2015).

One of the most extensive recent attempts to measure political quality in this literature compares all elected politicians to the population over three decades in Sweden. Drawing on detailed individual information on social background, party preferences, and test results on intelligence, income and leadership skills, evidence is found for positive, not adverse, political selection from the population (Dal Bó , Finan, Folke, Persson, and Rickne. 2017). Positive political selection is possible, and even becomes stronger as competition increases. While these findings seem to be reflected in recent work on Denmark (Dahlgard et al, 2019), the results are very different in the United States (Thompson et al, 2019).

More work needs to be done in improving measures of political elite types, and repeating the analysis in different settings, in order to understand how well results on positive or adverse selection travel. Political selection of specific elites can result in political inequality over time, via political careers, or incumbency and promotion. 


\subsection{Elections and political careers}

The political quality of those elected, perceived or real, could increase through time. A long literature on the incumbency advantage confirms that experienced legislators enjoy re-election advantages, at least partly because incumbency is viewed as a signal of legislator political quality (e.g. Erikson, 1971, Gelman and King, 1990).

Theoretical reasons for the incumbency advantage range from the ability to directly use the perks of one's office to obtain re-election, to attracting more campaign funding by signalling competence, or scaring off potential strong competitors (Erikson, 1971, Gelman and King, 1990, Ashworth and Bueno de Mesquita 2008). For political selection and political inequality, the question is to what extent incumbency provides direct advantages that cannot be explained by political quality or its increase over time. By comparing close winners to close losers in elections, and under the assumption that winning is quasi-exogenously determined, we can assess the effect of winning when quality differentials are close to zero.

To identify a causal impact of election on re-election, Lee (2008) first employed such methods of causal identification to estimate the The incumbency advantage typically measured in this and other natural experimental designs is the combined personal and partisan incumbency advantage, e.g. the perks of holding office to aid re-election, as well as the transferable advantage for an incumbent party (Erikson and Titiunik, 2015). Yet by exploiting term limits to separate out personal and partisan advantages, the partisan advantage was estimated to be near zero, suggesting that parties cannot use their resources to advantage candidates succeeding party incumbents, and that most of the incumbency advantage is personal (Fowler and Hall, 2014). Eggers and Spirling (2015) further showed that the incumbency advantage is largest 
in contexts where partisan preferences are weak. Finally, recent work has also started to identify institutional causes for incumbency advantages and disadvantages, such as the influence of young regimes or weak parties (Klašnja, 2015, Klašnja and Titiunik, 2017). Therefore, specific democratic institutions, among which party and electoral systems, clearly affect the size of the incumbency advantage. Electoral system minutiae have indeed long been recognized to affect re-election prospects. The incumbency advantage can be larger or smaller depending on how much institutions encourage the development of a personal vote (e.g. Ansolabehere, Snyder, and Stewart, 2000, Gelman and King 1990, Blais, et al., 2011, Cain, Ferejohn, and Fiorina, 1987) or strategic voting behaviour (Van der Straeten, Laslier, and Blais, 2013).

The evidence that parties can benefit from incumbency is limited, which indicates that incumbency advantages are personal. This makes it all the more surprising that in some contexts, incumbency advantages do seem to be transferable to family relatives (Dal Bó, Dal Bó and Snyder, 2005, Querubin, 2015, Fiva and Smith, 2015, Smith, 2018, Van Coppenolle, 2017). ${ }^{6}$ The inter-personal, dynastic incumbency advantage is an incumbency advantage that benefits the relatives of those who narrowly won their (re-)election bids. Moreover, the inter-personal incumbency advantage is larger in less party-centred, or elite-dominated, contexts that encourage more personal voting, like the US, than Norway, the Philippines or the UK (Dal Bó, Dal Bó, and Snyder, 2009; Cruz, Labonne and Querubin, 2017; Feinstein, 2010; Fiva and Smith, 2017; Smith, 2012; Van Coppenolle, 2017).

Besides re-election, another important influence on a legislator's political career, affecting what she can do for her constituents in office, are party rules and parliamentary procedures determining who will advance in the parliamentary or party hierarchy. 
What evidence is there on which individuals tend to be promoted? Once elected, legislators who perform better tend to be promoted more quickly within the party ranks, which is arguably not due to selection effects, but works through learning, or increased political quality over time (Padro í Miquel and Snyder, 2006, Wawro, 2000). The evidence for the transferability of advantages within parliaments to relatives is even more limited, but we know that relatives of previous cabinet ministers are more likely to obtain cabinet seats (Martin and Smith, 2017, Van Coppenolle, 2017).

Given these strong incumbency advantages and lack of legislator turnover, the discipline's comparative lack of attention in the past to individual political elites as opposed to parties, movements or institutions is perhaps unsurprising. Yet such lack of turnover in political elites can indicate persistent political inequality. Dynastic turnover can be expected to be lower in democracies, but was also found to vary among democracies (see Smith, 2018). Can political quality differentials explain such adverse or positive political selection over time, resulting from past institutional choices? Given the strong influence that electoral institutions seem to have on incumbency advantages, including the inter-personal incumbency advantage, isolating institutional consequences of elections for political selection is important.

\subsection{Selection beyond elections}

Beyond elections, equally important for political inequality is how politicians are selected for specific roles or for promotion after they enter parliament. There is a long literature studying the history of parliaments, their procedures and rules (e.g. Howe, 2010, Manow, Schroeder and Nickel, 2011, Koß, 2018), and of political careers,

for example of who gets to go on to serve as a government minister (e.g. Best and 
Cotta, 2000, Berlinski, Dewan, and Dowding, 2007, Blondel and Thiébault, 1991). Individual legislators are socialized into different roles (Blomgren and Rozenberg, 2012). Much of the chamber's law-making activity takes place in smaller committees, the selection of which is beyond voters' direct control (Martin, 2014). Beyond elections, both procedural and party rules affect what a legislator can do once in office, immediately and over a long career.

Recent developments in this literature use natural experiments, and institutional randomization, to study the connection between specific intra-parliamentary procedures and politician selection and behaviour. They include the study of the relevance of committee positions for future careers (Broockman and Butler 2015; Grimmer and Powell 2013), the relevance of seniority rules for committee selection (Cirone et al. 2019; Kellermann and Shepsle 2009), or of lottery-based procedures (Cirone and Van Coppenolle, 2018). The latter are important alternative selection mechanisms to seniority or election within parliaments, that allow us to learn about different selection institutions and their effects on political quality.

Studying such alternative selection mechanisms is crucial as some believe overreliance on elections for selection in representative democracies is one of its crucial flaws (e.g. Van Reybrouck, 2016), explaining why our democracies are in crisis (e.g. Grossman and Sauger, 2017), with persistent levels of political inequality. Elections only became inextricably linked to the word democracy in the course of the 19th century (Hayat, 2015, Ihl and Déloye, 1991, Rosanvallon, 1995, Sintomer, 2011), and elites experimented with alternatives like lotteries (Manin, 1997, Cirone and Van Coppenolle, 2019). We studied these lottery-based procedures for selection within parliaments.

We first drew on an extensive dataset of legislators in the French Third Republic 
to estimate the causal effect of committee service on legislative behaviour, re-election, and further parliamentary and party careers. We exploited a natural experiment in the French Third Republic (1870-1940), created by the yearly lotteries that divided the legislature into groups that nominated members to the budget committee. We found that committee appointment increased legislative entrepreneurship concerning budget-related but not other types of legislation, suggesting specialized skill acquisition, a measure of political quality. We also found career promotion specific to these legislative skills (i.e. ministerial promotion, but not to the party leadership or senate), but no effects on re-election. While we showed how lottery-based procedures can still encourage skill acquisition, others have shown they have real policy consequences: Considering lotteries for the selection of political leaders in the medieval city-state of Florence, Abrahamson (2019) found that the randomly drawn leaders' economic interests affected the city's exchange rates.

An additional advantage of these studies is that they show how alternative political selection mechanisms work in real political settings (benefits have been shown in experiments with citizens, see Dryzek et al, (2019)). Experiments with lotteries are nearly impossible to conduct today, as elections confer legitimacy to the democratic process, and political parties and elites have vested interests in controlling selection. In a follow-up analysis of the use and abolishment of this lottery-based procedure, we found that lotteries help to support weak party systems, while they tend to be abolished once parties become stronger, and want to control legislator career incentives (Cirone and Van Coppenolle, 2019). As democratic institutions are rarely drastically changed, there is real benefit to understanding initial institutional consequences. 


\section{Conclusion}

Populist movements across democracies point at persistent tensions between political elites and citizens. This article discussed formal and empirical research on the selection of elites, their behaviour, and their persistence over the long run. Elites can persist because incumbents tend to hold an advantage in election and promotion, and because these benefits may be transferable to family relatives. Are these persistent inequalities consequences of how democracies organize political selection? There is much variation in the political quality of representatives, as well as in political inequality, between countries and over time. Using historical data, recent work attempts to isolate the institutional effects on political selection, which can increase

political inequality over time. How elections and legislative organization affect dynastic persistence, compared to potential alternatives such as lotteries, is understudied, and forms an important research agenda for those interested in political inequality. Such empirical historical research could help distinguish institutional consequences from original choices, and explain the origins of today's democratic political institutions from the perspectives of individual elites. If democratic institutional reform removed hereditary selection, why did elites introduce these reforms? When is power inheritable, when is it not, and what can institutions do? These questions are important in a world of increasing economic inequality. 


\section{Notes}

${ }^{1}$ See Becher et al, 2017; Bedock, 2014, 2017; Koß, 2018 to understand individual legislative, and executive support for (and obstruction of) institutional change in representative democracies.

${ }^{2}$ Research designs for causal inference are now widely employed throughout the social sciences (e.g. Banerjee and Duflo, 2009, Lee and Lemieux, 2010)

${ }^{3}$ It is likely that merely identifying a characteristic as politically relevant by building representative institutions reflecting the divisions, makes it so.

${ }^{4} \mathrm{~A}$ decrease in the capacity to remember at least one representative's name indicates that such electoral system rules also affect how politicians campaign using more individual messages (Van Coppenolle, 2017) under certain electoral rules.

${ }^{5} \mathrm{~A}$ natural experiment is a case where "the assignment of treatments to subjects is haphazard and possibly random" (Sekhon and Titiunik, 2012). These techniques effectively exclude potentially confounding factors from the causal relation of interest. This approach relies on a number of assumptions, which are not always met, but can be supported by statistical tests (Eggers et al, 2015). A key limitation of natural experiments is that the experiment is typically restricted to a particular context. Therefore, careful interpretation of the external validity of findings across space and time is essential.

${ }^{6}$ As measured by education levels, dynastic candidates were in some cases found to be of lower political quality (Geys, 2017). 


\section{References}

[1] Abrahamson, S. 2016. 'The Economic Effects of Leaders' Economic Interests: Evidence from Election by Lot in the Florentine Republic', Unpublished paper, University of Rochester.

[2] Acemoglu, D. and J. Robinson. 2008. 'Persistence of Power, Elites and Institutions', American Economic Review 98(1):267-293.

[3] Acemoglu, D., M. A. Bautista, P. Querubin, and J. A. Robinson. 2008. 'Economic and Political Inequality in Development: The Case of Cundinamarca, Colombia', in ed. Elhanan Helpman, Institutions and Economic Performance, Cambridge, Massachusetts: Harvard University Press: 181-248.

[4] Ansolabehere, S., J. Snyder, and C. Stewart. 2000. 'Old Voters, New Voters, and the Personal Vote: Using Redistricting to Measure the Incumbency Advantage', American Journal of Political Science, 1 (44): 17-34.

[5] Ashworth, S. and E. Bueno de Mesquita. 2008. 'Electoral Selection, Strategic Challenger Entry, and the Incumbency Advantage', The Journal of Politics, 70 (4): 1006-1025

[6] Banerjee, A. V. and E. Duflo. 2009. 'The Experimental Approach to Development Economics', Annual Review of Economics, 1 (1), 151-178.

[7] Becher, M., S. Brouard, I. Guinaudeau, 2017. 'Prime ministers and the electoral cost of using the confidence vote in legislative bargaining: evidence from France', West European Politics, 40 (2): 252-274 
[8] Bedock, C. 2014. 'Explaining the determinants and processes of institutional change', French Politics, 12 (4): 357-374

[9] Bedock, C. 2017. Reforming democracy: institutional engineering in western Europe. Oxford: Oxford University Press.

[10] Benoit, K. 2004. 'Models of electoral system change', Electoral Studies, 23: 363-389. Berlinski, S. T. Dewan, and Dowding, K. 2007. 'The Length of Ministerial Tenure in the UK 1945-1997', British Journal of Political Science, $37(2): 245-262$

[11] Berlinski, S., T. Dewan, and B. Van Coppenolle. 2014. 'Franchise Extension and the British Aristocracy', Legislative Studies Quarterly, 39 (4): 531-558

[12] Berlinski, S., T. Dewan, and B. Van Coppenolle. 2015. 'Political Inequality in the UK 1832-1997', Unpublished.

[13] Besley, T. 2005. 'Political Selection', The Journal of Economic Perspectives, $19(3): 43-60$

[14] Besley, T. and S. Coate. 1997. 'An Economic Model of Representative Democracy', Quarterly Journal of Economics, 112 (1): 85-114

[15] Besley, T. and M. Reynal-Querol. 2011. 'Do democracies select more educated leaders?', American Political Science Review, 105 (3): 552-566

[16] Besley, T., J. G. Montalvo, and M. Reynal-Querol. 2011. 'Do educated leaders matter?', The Economic Journal, 121 (554): 205-227

[17] Best, H. and M. Cotta. (eds.). 2000. Parliamentary Representatives in Europe 1848-2000. Oxford: Oxford University Press. 
[18] Blais, A., R. Lachat, , A. Hino, and P. Doray-Demers. 2011. 'The Mechanical and Psychological Effects of Electoral Systems: A Quasi-experimental Study', Comparative Political Studies, 44: 1599-1621.

[19] Blomgren, M. and O. Rozenberg. (eds.). 2012. Parliamentary Roles in Modern Legislatures, New York: Routledge.

[20] Blondel, J. and J-L. Thiébault. 1991. The Profession of Government Minister in Western Europe. Basingstoke, UK: Palgrave Macmillan

[21] Broockman, D. and D. Butler. 2015. "Do Better Committee Assignments Meaningfully Benefit Legislators? Evidence from a Randomized Experiment in the Arkansas State Legislature." Journal of Experimental Political Science, 2 no.2: 152-163.

[22] Brouard, S., O. Costa, E. Kerrouche, and T. Schnatterer. 2013. 'Why do French MPs Focus More on Constituency Work than on Parliamentary Work?', The Journal of Legislative Studies, 19 (2): 141-159.

[23] Cain, B. E., J A. Ferejohn, and M. P. Fiorina. 1987. The Personal Vote: Constituency Service and Electoral Independence. Cambridge, MA: Harvard University Press.

[24] Canandine, D. 1999. The Decline and Fall of the British Aristocracy. New York: Vintage.

[25] Capoccia, G. and D. Ziblatt. 2010. 'The Historical Turn in Democratization Studies: A New Research Agenda for Europe and Beyond', Comparative Political Studies, 43 (8-9): 931-68. 
[26] Carnes, N. and N. Lupu. 2015. 'What Good Is a College Degree? Education and Leader Quality Reconsidered,' The Journal of Politics, 78(1): 35-49.

[27] Caselli, F. and Morelli, M. 2004. 'Bad Politicians', Journal of Public Economics, $88(3-4): 759-782$

[28] Cirone, A. and Van Coppenolle, B. 2018. 'Cabinets, Committees and Careers: The Causal Effect of Committee Service', The Journal of Politics, 80 (3): 948963.

[29] Cirone, A. and Van Coppenolle, B. 2019. 'Bridging the Gap: Lottery-based Procedures in Early Parliamentarization', World Politics', 71(2): 197-235.

[30] Cruz, C., J. Labonne, and P. Querubin. 2017. 'Politician Family Networks and Electoral Outcomes: Evidence From the Philippines,' American Economic Review, 107 (10): 3006-3037.

[31] Dahlgad, J. O. and R. T. Pedersen, and L. H. Pedersen. 2019. 'Must Voters Choose Between Political Competence and Descriptive Representation?, Unpublished: Copenhagen Business School.

[32] Dal Bó, E., P. Dal Bó, and J. Snyder. 2009. 'Political Dynasties', Review of Economic Studies, 76 (1): 115-142.

[33] Dal Bó, E., F. Finan, O. Folke, T. Persson and J. Rickne. 2017. 'Who Becomes A Politician?', The Quarterly Journal of Economics, 132(4): 1877-1914.

[34] Dryzek, J. S., Bachtiger, A., Chambers, S., Cohen, J., Druckman, J. N., Felicetti, A., Fishkin, J. S., Farrell, D. M., Fung, A., Gutmann, A., Landemore, H., Mansbridge, J., Marien, S., Neblo, M. A., Niemeyer, S., Setala, M., 
Slothuus, R., Suiter, J., Thompson, D. and Warren, M. E. 2019. 'The Crisis Of Democracy And The Science Of Deliberation', Science, 363(6432):1144-1146.

[35] Eggers, A. C. and A. Spirling. 2017. 'Incumbency Effects and The Strength of Party Preferences: Evidence from Multiparty Elections in the United Kingdom', The Journal of Politics, 79, no. 3 (July 2017): 903-920.

[36] Eggers, A., A. Fowler, J. Hainmueller, A. B. Hall and J. M. Snyder, Jr. 2015. 'On the Validity of the Regression Discontinuity Design for Estimating Electoral Effects: New Evidence from over 40,000 Close Races', American Journal of Political Science, 59 (1): 259-274.

[37] Erikson, R. S. 1971. 'The advantage of incumbency in Congressional Elections', Polity, 3 (3): 395-405

[38] Erikson and Titiunik, 2015. 'Using Regression Discontinuity to Uncover the Personal Incumbency Advantage', Quarterly Journal of Political science,

[39] Feinstein, B. D. 2010. 'The Dynasty Advantage: Family Ties in Congressional Elections', Legislative Studies Quarterly, 35: 571-98.

[40] Fiva, J. H and D. M. Smith. 2017. 'Political Dynasties and the Incumbency Advantage in Party-Centered Environments', American Political Science Review, 3 (112): 706-712.

[41] Fowler, A. and A. B. Hall, 2014. 'Disentangling the personal and partisan incumbency advantages: Evidence from close elections and term limits', Quarterly Journal of Political Science, 9 (4): 501-531. 
[42] Gelman, A. and G. King. 1990. 'Estimating the Incumbency Advantage without Bias', American Journal of Political Science, 34(4): 1142-1164.

[43] Geys, B. 2017. 'Political Dynasties, Electoral Institutions and Politicians' Human Capital', The Economic Journal, 127: F474-F494.

[44] Grimmer, J. and E. Powell. 2013. "Congressmen in Exile: The Politics and Consequences of Involuntary Committee Removal." The Journal of Politics, 75 (4): $907-920$.

[45] Grossman, E. and N. Sauger. 2017. Pourquoi détestons-nous autant nos politiques?, Paris : Presses de Sciences Po.

[46] Hayat, S. 2015. 'The Revolution of 1848 in the History of French Republicanism', History of Political Thought, 36 (2): 332-353.

[47] Howe, P. J. 2010. 'Electoral Institutions and Ethnic Group Politics in Austria, 1867-1914', Nationalism and Ethnic Politics 16 (2): 164-91.

[48] Ihl, O. and Y. Déloye. 1991. 'Des voix pas comme les autres. Votes blancs et votes nuls aux élections législatives de 1881', Revue française de science politique, 31 (2): 141-170.

[49] Kellerman, M. and K. Shepsle. 2009. 'Congressional Careers, Committee Assignments, and Seniority Randomization in the US House of Representatives', Quarterly Journal of Political Science, 4: 87-101.

[50] Klasňja, M. 2015. 'Corruption and Incumbency Disadvantage: Theory and Evidence', The Journal of Politics, 4 (77): 928-942 
[51] Klasňja, M. and R. Titiunik. 2017. 'The Incumbency Curse: Weak Parties, Term Limits, and Unfulfilled Accountability', American Political Science Review, 1 (111): 129-148

[52] Koß, M. 2018. 'Parliaments in Time: The Evolution of Legislative Democracy in Western Europe, 1866-2015', Habilitation, Ludwig-Maximilians-Universität München.

[53] Krehbiel. 1993. 'Where's the party?' British Journal of Political Science, 23: $235-66$.

[54] Lee, D. S. 2008. "Randomized Experiments from Non-random Selection in U.S. House Elections" Journal of Econometrics, 142: 2: 675-697.

[55] Lee, D. S. and T. Lemieux. 2010. "Regression Discontinuity Designs in Economics" Journal of Economic Literature, 48, 281-355.

[56] Manin, B. 1997. The Principles of Representative Government, Cambridge University Press.

[57] Manow, P.,V. Schroeder, and C. Nickel. 2011. 'Germany's 1918 Electoral Reform and the Reichstag's 'Efficient secret', Unpublished.

[58] Martin, S. 2014. 'Committees' in Martin, S.,T. Saalfeld, and K. W. Strøm (eds) The Oxford Handbook of Legislative Studies, Oxford: Oxford University Press.

[59] Martin, S. and D. M. Smith. 2017. ' Political Dynasties and the Selection of Cabinet Ministers', Legislative Studies Quarterly, 
[60] Mattozzi, A. and A. Merlo. 2007. "The Transparency of Politics and the Quality of Politicians." American Economic Review 97(2):311-315.

[61] Mattozzi, A. and A. Merlo. 2008. "Political careers or career politicians?" Journal of Public Economics 92(3-4):597-608.

[62] Mattozzi, A. and E. Snowberg. 2018. 'The right type of legislator: A theory of taxation and representation', Journal of Public Economics, 159: 54-65

[63] Messner, M. and M. K. Polborn. 2004. "Paying Politicians." Journal of Public Economics 88(12): 2423-2445.

[64] McCarty, N, K. T. Poole, . and H. Rosenthal. 2005. Polarized America: The Dance of Ideology and Unequal Riches, London: MIT University Press.

[65] Michels, R. [1911] 1968. Political parties: a sociological study of the oligarchical tendencies of modern democracy, translated by Paul, Eden and Paul, Cedar, New York: The Free Press, 2nd Free Press paperback.

[66] Mosca, G. [1896] 1939. The ruling class (Elementi di scienza politica), translation by Hannah D. Kahn ed. New York, London: McGraw-Hill.

[67] Norris, P. 2004. Electoral Engineering: Voting Rules and Political Behavior. Cambridge : Cambridge University Press.

[68] Offerlé, M. 1993. 'Usages et usure de l'hérédité en politique', Revue française de science politique, $43(5): 850-856$.

[69] Osborne, M. J. and A. Slivinski. 1996. "A Model of Political Competition with Citizen-Candidates" Quarterly Journal of Economics, 111 (1): 65-96. 
[70] Padró i Miquel, G. and J. M. Snyder. 2006. 'Legislative Effectiveness and Legislative Careers', Legislative Studies Quarterly 31 (4): 347-81.

[71] Pande, R. 2003. "Can mandated political representation increase policy influence for Disadvantaged Minorities? Theory and Evidence from India." American Economic Review 93(4):1132-1151

[72] Piketty, T. 2014. Capital in the twenty-first century, Harvard University Press.

[73] Pitkin, H. F. 1967. The Concept of Representation, Berkeley: University of California Press.

[74] Querubin, P. 2015. 'Family and Politics: Dynastic Incumbency Advantage in the Philippines', Quarterly Journal of Political Science, 11 (2): 151-181.

[75] Ricart-Huguet, J. 2019. ' Who Governs? Colonial Education and Regional Political Inequality in Africa', Unpublished: Yale.

[76] Rosanvallon, P. 1995. "The History of the Word "Democracy" in France', Journal of Democracy, 6 (4): 139-153.

[77] Rush, M. 2001. The Role of the Members of Parliament since 1868: From Gentlemen to Players. New York: Oxford University Press.

[78] Schofield, N. 2003. 'Valence competition in the spatial stochastic model', Journal of Theoretical Politics, 15 (4): 371-383

[79] Sekhon, J. S and R. Titiunik. 2012. 'When Natural Experiments Are Neither Natural nor Experiments', American Political Science Review, 106 (1): 35-57. 
[80] Shugart, M. S, M. E. Valdini and K. Suominen. 2005. "Looking for Locals: Voter Information Demands and Personal Vote-Earning Attributes of Legislators under Proportional Representation." American Journal of Political Science 49(2): 437-449.

[81] Smith, D. M. 2012. 'Succeeding in Politics: Dynasties in Democracies', PhD thesis, University of California, San Diego.

[82] Smith, D. M. 2018. 'Dynasties in Democracies: The Inherited Incumbency Advantage in Japan', Stanford California: Stanford University Press.

[83] Sintomer, Y. 2011. 'Tirage au sort et politique: de l'autogouvernement républicain à la démocratie délibérative', Raisons politiques, 42: 159-186.

[84] Thompson, D. M. and J. J. Feigenbaum, A. B. Hall, and J. Yoder. 2019. 'Who Becomes a Member of Congress? Evidence From De-Anonymized Census Data', Unpublished: Stanford University.

[85] Van Coppenolle, B. 2017. 'Political Dynasties in the UK House of Commons: The Null Effect of narrow Electoral Selection', Legislative Studies Quarterly, $42(3): 449-475$.

[86] Van Coppenolle, B. 2018. 'Remembering one's Representative: How District Magnitude and List Type affect Candidate Recognition', Political Studies, 66(3): $786-807$.

[87] Van der Straeten K., J.-F. Laslier, and A. Blais. 2013. 'Vote Au Pluriel: How people vote when offered to vote under different rules?', PS: Political Science and Politics, 46(2): 324-328. 
[88] Van Reybrouck, D. 2016. Against Elections: The Case for Democracy, Bodley Head Publishers.

[89] Wallack, J. 2008. 'India's Parliament as a Representative Institution,' India Review, 7 (2).

[90] Washington, E. L. 2009. 'Female Socialization: How Daughters Affect Their Legislator Fathers' Voting on Women's Issues', American Economic Review, 98 (1): 311-332

[91] Wasson, E. A. 1991. 'The House of Commons, 1660-1945: Parliamentary Families and the Political Elite', The English Historical Review, 106 (420): 635-651

[92] Wawro, G. 2000. Legislative Entrepreneurship in the U.S. House of Representatives. Ann Arbor: University of Michigan Press. 